\title{
ANTIHYPERGLYCEMIC AND ANTIHYPERLIPIDEMIC ACTIVITY OF JATROPHA GOSSYPIFOLIA METHANOLIC EXTRACT IN STREPTOZOTOCIN-NICOTINAMIDE INDUCED DIABETIC RATS
}

\author{
ISSAC PRAVEEN KUMAR ${ }^{1}$, ISHAN MALHOTRA ${ }^{1}$, SUJATHA SUNDARESAN ${ }^{1 *}$, ALWIN DEV ${ }^{2}$ \\ ${ }^{1}$ Department of Biotechnology, School of Bioengineering, SRM University, Kattankulathur, Kancheepuram, Tamil Nadu, India. ${ }^{2}$ Department \\ of Animal House, SRM Medical College Hospital and Research Centre, SRM University, Kattankulathur, Tamil Nadu, India. \\ Email: sujatha.sa@ktr.srmuniv.ac.in \\ Received: 27 June 2017, Revised and Accepted: 08 August 2017
}

ABSTRACT

Objective: The objective of the present study is to explore the antihyperglycemic and antihyperlipidemic activities of Jatropha gossypifolia methanolic extract (ME) in streptozotocin (STZ)-nicotinamide (NIC) induced diabetic model.

Methods: Type II diabetes was induced by a single dose of NIC (110 mg/kg) and STZ (50 mg/kg b.w.) intraperitoneally. The diabetic animals were treated with ME (50 mg/kg and $100 \mathrm{mg} / \mathrm{kg}$ b.w.) of J. gossypifolia. At the end of experimental period, the effect of the ME on creatinine level, triglyceride (TG), total cholesterol (TC), high-density lipoprotein (HDL), low-density lipoprotein (LDL) and very LDL (VLDL) were analyzed. Liver function parameters such as glutamate oxaloacetate transaminase (GOT), glutamate pyruvate transaminase (GPT) were analyzed and liver glycogen content was estimated spectrophotometrically. After scarification of animals, the liver was collected and subjected to histopathology analysis. Glycogen content was estimated spectrophotometrically.

Results: The ME treated diabetic rats showed a significant increase in HDL level and a decrease in creatinine, TG, TC, and VLDL levels. The treated group showed a significant decrease in liver function parameters such as GOT and GPT levels and significantly increased the liver glycogen content.

Conclusion: These findings demonstrate that ME possess antihyperglycemic and antihyperlipidemic activity against STZ - NIC induced diabetic rats.

Keywords: Jatropha gossypifolia, Methanolic extract, Streptozotocin-nicotinamide induction, Antihyperglycemic, Antihyperlipidemic.

(C) 2017 The Authors. Published by Innovare Academic Sciences Pvt Ltd. This is an open access article under the CC BY license (http://creativecommons. org/licenses/by/4. 0/) DOI: http://dx.doi.org/10.22159/ajpcr.2017.v10i11.20985

\section{INTRODUCTION}

Diabetes mellitus (DM) is a metabolic disorder characterized by hyperglycemia arising as a consequence of relative or absolute deficiency of insulin secretion, resistance to insulin action or both [1]. The main pathophysiological defect of Type II diabetes is insulin resistance, a decrease in cellular response to insulin. This includes impairment in the insulin signaling pathway leading to a failure of the insulin-stimulated glucose uptake in targeted tissues such as muscle and fat [2].

The classic symptoms associated with diabetes are polyuria (condition of increased urination), polydypsia (increased thirst), and polyphagia (increased hunger). Other important mechanisms associated with Type II diabetes includes high glucagon levels in blood, increased breakdown of lipids within the fat cells, resistance to incretion and increased retention of salt and water by the kidneys [3,4] and hypercholesterolemia, a condition associated with an increased plasma concentration of LDL, VLDL, and elevated levels of HDL [5]. Obesity combined with insulin resistance is a major risk factor for the prevalence of non-insulin dependent diabetes mellitus [6]. Adipocyte is the only apparent link between diabetes and obesity, which stores excess glucose in the form of fat by changing dramatically in its size in accordance with metabolic needs [7]

Many medicinal herbs from Indian system of medicine have been shown to have hypoglycemic and hypolipidemic properties due to the presence of various secondary metabolites such as alkaloids, terpenoids, flavonoids, saponins, and tannins [8-10]. Glucoselowering drugs including sulfonylureas, biguanides, alpha-glucosidase inhibitors, thiazolidinediones, and meglitinides have been shown for their effectiveness in governing diabetic signs, and most of them have been conveyed to pose one or other physiological complication or side effects on use [11]. Jatropha gossypifolia is a perennial herb belonging to the Euphorbiaceae family with the common name of bellyache bush. The plant has hairy leaves with three lobed fruit and flowers. Various parts of the plant such as leaves, roots, and stem bark are of medicinal importance [12]. Abreu et al. have reported that J. gossypifolia has antihypertensive activity [13]. Plant of this genus such as Jatropha curcas and Jatropha tanjorensis has been reported for antidiabetic activity $[14,15]$. Hence, this study was taken, to investigate the antihyperglycemic and antihyperlipidemic activities of the leaves of J. gossypifolia in streptozotocin (STZ)-nicotinamide (NIC) induced diabetic rats.

\section{METHODS}

Chemicals and reagents

Metformin, NIC were obtained from Himedia, India. STZ was purchased from Sigma-Aldrich, St. Louis, USA. Organic solvents were of the highest analytical grade. All other fine chemicals, organic solvents, and reagents used were of higher analytical grade and purchased from Himedia, India.

Collection of plant material, extraction, and phytochemical constitution

J. gossypifolia leaves were collected from Chennai, Tamil Nadu, India. The collected material was authenticated in a plant anatomy research institute (PARC/2015/3142), Chennai, Tamil Nadu, India. Leaves were shade dried, powdered and packed in the Soxhlet apparatus and extracted with methanol. The extraction was carried out for $72 \mathrm{hrs}$ at $60^{\circ} \mathrm{C}$. The extract was filtered and concentrated in a rotary evaporator. 
The extract was stored at room temperature for further analysis. Preliminary phytochemical screening for the presence of flavonoids was done by colorimetric aluminum chloride method [16], total phenolic content [17], and tannin content was done by Folin-Ciocalteu method $[18,19]$.

\section{Experimental group}

The in vivo study was in accordance to the animal Institutional Ethical Committee (ethical clearance no 090/835/IAEC-2014). Male Wistar rats, of 6 to 8 was old and weighing $150-200 \mathrm{~g}$, were used for the study. Totally, 45 animals were purchased from Tamil Nadu Veterinary and Animal Sciences University, Chennai, India, and were acclimatized in the Center for Animal House, SRM University, Chennai, India. All animals were acclimatized to laboratory conditions for one week and allowed free access to sterilized water and pellet diet. The rats were maintained in sterilized polypropylene cages with sterile paddy husk as bedding and maintained in $12 \mathrm{hrs}$ light $+12 \mathrm{hrs}$ dark cycle at temperature $\pm 25^{\circ} \mathrm{C}$.

\section{Development of insulin resistant animal model}

Diabetes was induced in male Wistar rats (aged 2-3 months and 180-200 g body weight) by intraperitoneal administration of NIC (110 mg/kg b.w.) and STZ (single dose of $50 \mathrm{mg} / \mathrm{kg}$ b.w.) dissolved in freshly prepared $0.01 \mathrm{M}$ citrate buffer, $\mathrm{pH}$ 4.5. STZ was injected after 15 minutes from the administration of NIC. NIC was freshly prepared in saline [20]. After checking the blood glucose levels at $3^{\text {rd }}$ day and $7^{\text {th }}$ day of induction, the rats with marked hyperglycemia (FBG $\geq 250 \mathrm{mg} / \mathrm{dl}$ ) were selected and used for the study [21].

\section{Animal grouping and drug administration}

A total of 45 rats ( 30 diabetic rats and 15 normal rats) were divided into six groups with five rats per group:

Group 1: Control rats (0.5\% CMC); $n=5$

Group 2: Control rats treated with methanolic extract (ME)

(100 mg/kg b.w.); n=5

Group 3: Diabetic rats (STZ+NIC); $\mathrm{n}=5$

Group 4: Diabetic rats treated with ME (50 mg/kg b.w.); $n=5$

Group 5: Diabetic rats treated with ME (100 mg/kg b.w.); $\mathrm{n}=5$

Group 6: Diabetic rats treated with metformin ( $500 \mathrm{mg} / \mathrm{kg} \mathrm{b.w.);} \mathrm{n}=5$.

All experiments were carried out in overnight fasted rats.

\section{Estimation of biochemical parameters}

The blood samples were collected using retro orbital plexus on $0^{\text {th }}$, $7^{\text {th }}, 14^{\text {th }}, 21^{\text {st }}, 28^{\text {th }}$, and $35^{\text {th }}$ day. Blood samples were allowed to clot for 30 minutes and centrifuged at $3000 \mathrm{rpm}$ for 15 minutes. The serum was collected and used for biochemical parameters such as creatinine level by Jaffe method. Total cholesterol (TC), triglyceride (TG), high-density lipoprotein (HDL), low-density lipoprotein (LDL) and very LDL (VLDL) estimated according to enzymatic GPO, trinder, and endpoint method. Liver function parameters such as glutamate oxaloacetate transaminase, glutamate pyruvate transaminase were done by International Federation of Clinical Chemistry method. All the biochemical parameters were carried out using commercially available test kits from Robonik prietest, India [22,23].

\section{Histopathological investigation}

At the end of the study period, control and treated group animals were sacrificed, and liver was dissected out for histopathological studies. After washing the samples with saline, they were stored in $10 \%$ formalin. The tissues were fixed in paraffin, and thin section ( $5 \mathrm{~mm}$ ) of samples were taken and stained with hematoxylin and eosin for microscopic assessment [24].

\section{Estimation of glycogen content}

Per g of liver, samples were rinsed with ice-cold buffer (saline) and incubated with $30 \% \mathrm{KOH}$ at $55^{\circ} \mathrm{C}$ for 30 min with occasional shaking. $0.2 \mathrm{ml}$ of sodium sulfate was added, and glycogen was precipitated by the addition of ethanol $(5 \mathrm{ml})$. The precipitate was removed and dissolved in $10 \mathrm{ml}$ of water. To this, $1 \mathrm{ml}$ of $1.2 \mathrm{~mol} / \mathrm{l} \mathrm{HCl}(1 \mathrm{ml})$ was added and boiled for $2 \mathrm{hrs}$ and neutralized with $0.5 \mathrm{~mol} / \mathrm{l} \mathrm{NaOH}$ and OD was taken at $620 \mathrm{~nm}[25,26]$.

\section{Statistical analysis}

The results were expressed as mean \pm standard deviation (SD). One-way analysis of variance (ANOVA) was used for data analysis, followed by Duncan's multiple range test (DMRT) using a Statistical Package for the Social Sciences (SPSS) software Version 17.0 for windows. The significance level was considered as $\mathrm{p}<0.05$.

\section{RESULTS AND DISCUSSION}

\section{Phytochemical constitution of J. gossypifolia ME}

Phytochemical screening of ME of J. gossypifolia showed the presence of phytochemical constituents such as tannins, flavonoids, and phenolic contents. The ME yield was found to be $9.6 \%(\mathrm{w} / \mathrm{w})$. Tannin content was found to be $1.732 \pm 0.001 \mathrm{mg} / \mathrm{ml}$, phenol content was $0.892 \pm 0.001 \mathrm{mg} / \mathrm{ml}$, and flavonoid content was found to be $1.3125 \pm 0.0015 \mathrm{mg} / \mathrm{ml}$. Previous reports have shown that the higher tannin, flavonoid, and phenol content have been extracted using methanol from various plant extracts due to its increased polarity [27-31]

\section{Effect of ME on creatinine level}

The effects of ME on serum creatinine level in control and experimental group rats are given in Table 1. In diabetic rats, the increased serum creatinine level was observed throughout the study which represents liver and renal damage to the diabetic rats from initial day $2.547 \pm 0.08\left(0^{\text {th }}\right.$ day $)$ until the end of the experiment $2.773 \pm 0.12\left(35^{\text {th }}\right.$ day). Oral administration of ME (50 and $100 \mathrm{mg} / \mathrm{kg}$ b.w.) to the experimental groups significantly reduced the creatinine level. ME low dose (LD) showed a reduction in creatinine level from $2.513 \pm 0.36\left(0^{\text {th }}\right.$ day - before treatment $)$ to $1.584 \pm 0.06\left(35^{\text {th }}\right.$ day - after treatment) whereas, high dose (HD) of ME exhibited a decrement from $2.515 \pm 0.38$ to $1.462 \pm 0.21$ in creatinine level. Administration of metformin also showed a decrease from $2.546 \pm 0.34$ to $1.398 \pm 0.28$ in creatinine level. The reduction in the creatinine level by ME supports its shielding nature on the liver and renal damage. Similarly, upsurge in creatinine level was decreased by administration of ethanolic extract (200 and $400 \mathrm{mg} / \mathrm{kg}$ b.w.) of Allium cepa Linn from $4.512 \pm 0.19$ to $2.475 \pm 0.147[32]$

\section{Effect of ME in TG and TC}

Table 2 illustrates the effect of ME on the level of serum TG and TC in control and experimental groups. The levels of TG $(248.11 \pm 3.98 \mathrm{mg} / \mathrm{dL})$ and TC $(279.420 \pm 3.99 \mathrm{mg} / \mathrm{dL})$ were significantlyincreased in the diabetic group rats until end of the study whereas administration of LD and HD of ME decreased the level of TG from $205.44 \pm 3.26$ to $129.38 \pm 2.97 \mathrm{mg} / \mathrm{dL}$ and $203.22 \pm 3.49$ to $117.07 \pm 2.94 \mathrm{mg} / \mathrm{dL}$. A significant decrease in the level of TC was observed at the end of the experiment $(195.116 \pm 2.92$ in LD ME and $178.801 \pm 2.25 \mathrm{mg} / \mathrm{dL}$ in HD ME). Diabetic mellitus is characterized by an elevation in cholesterol and TG levels which are

Table 1: Effect of ME on serum creatinine in STZ-NIC induced diabetic rats $(n=5)$

\begin{tabular}{|c|c|c|}
\hline \multirow[t]{2}{*}{ Groups } & \multicolumn{2}{|c|}{ Creatinine mg/dL } \\
\hline & $\begin{array}{l}\text { Before } \\
\text { treatment }\end{array}$ & $\begin{array}{l}\text { After } \\
\text { treatment }\end{array}$ \\
\hline Control & $1.248 \pm 0.06$ & $1.206 \pm 0.07$ \\
\hline Control+J. gossypifolia & $1.224 \pm 0.07$ & $1.209 \pm 0.06$ \\
\hline Diabetic group & $2.547 \pm 0.08^{\#}$ & $2.773 \pm 0.12^{\#}$ \\
\hline Diabetic+J. gossypifolia ME (LD) & $2.513 \pm 0.36$ & $1.584 \pm 0.06^{*}$ \\
\hline Diabetic+J. gossypifolia ME (HD) & $2.515 \pm 0.38$ & $1.462 \pm 0.21^{*}$ \\
\hline Diabetic+metformin & $2.546 \pm 0.34$ & $1.398 \pm 0.28^{*}$ \\
\hline
\end{tabular}

Values are expressed as means $\pm \mathrm{SD}(\mathrm{n}=5)$ from three independent experiments. Statistical evaluation was done by one-way ANOVA followed by DMRT. ${ }^{*} \mathrm{p}<0.05$ as compared with diabetic group, ${ }^{*} \mathrm{p}<0.05$ as compared with control group. J. gossypifolia: Jatropha gossypifolia, LD: Low dose, HD: High dose, STZ-NIC: Streptozotocin-nicotinamide, ME: Methanolic extract 
termed as hyperlipidemia. The results clearly showed that ME brought TG and TC levels to normal due to increase in the level of insulin secretion which inhibits lipases and decreases the fat deposition and upturn the consumption of glucose.

Similarly, TG and TC level was found to be significantly $(\mathrm{p}<0.001)$ lesser than the diabetic group in various fractions of Annona reticulata leaf. The TG levels of various groups at the end of the experimental day were $195.49 \pm 10.038 \mathrm{mg} / \mathrm{dL}$ to methanolic fraction treated group and $198.32 \pm 15.827 \mathrm{mg} / \mathrm{dL}$ ethyl acetate fraction treated group and cholesterol level were found to be $114.45 \pm 4.531 \mathrm{mg} / \mathrm{dL}$ in methanolic fraction treated group and $61.65 \pm 5.255 \mathrm{mg} / \mathrm{dL}$ for ethyl acetate fraction treated group [33].

\section{Effect of ME on lipid profile}

STZ-NIC induced diabetic group rats showed increased level of LDL $(209.07 \pm 3.48 \mathrm{mg} / \mathrm{dL})$ which increases the coronary risk factor and decreased the level of HDL $(21.72 \pm 1.07 \mathrm{mg} / \mathrm{dL})$ which are shown to have a cardiovascular risk factor. The increase in the level of TG and TC is concomitant with increased level of LDL, VLDL, and decrease the level of HDL. Treatment to the STZ-NIC induced diabetic groups with two doses of (50 and $100 \mathrm{mg} / \mathrm{kg}$ b.w.) ME significantly reduced the level of LDL and VLDL level and increased HDL level as compared with the diabetic rats (Table 3). The lipid profile level of various groups at $35^{\text {th }}$ day for HDL was $49.83 \pm 1.96$ and $54.38 \pm 1.08 \mathrm{mg} / \mathrm{dL}$ and LDL level at the final day was $120.17 \pm 2.24$ and $101.31 \pm 2.04 \mathrm{mg} / \mathrm{dL}$ followed by VLDL at $25.87 \pm 1.32$ and $23.40 \pm 1.37 \mathrm{mg} / \mathrm{dL}$ corresponding to LD and HD of ME, respectively. The result suggests that the ME has considerably dropped the blood lipid irregularities. Previous studies with Achatina fulica $(0.5 \mathrm{mg}) \mathrm{ME}$ dissolved in $1 \%$ gum acacia in alloxan - induced diabetic mice showed antihyperlipidemic activities, which supports our data [34].

\section{Liver enzyme parameters}

Table 4 indicates the decrease in serum aspartate transaminase (AST) and alanine transaminase (ALT) levels up on oral administration of ME (LD and HD) showed 38.236 \pm 1.29 and $36.488 \pm 1.26 \mathrm{U} / \mathrm{L}$ AST level and $40.236 \pm 2.27$ and $37.688 \pm 1.24 \mathrm{U} / \mathrm{L}$ ALT levels, respectively. A significant increase in the serum AST $(191.314 \pm 2.82 \mathrm{U} / \mathrm{L})$ and ALT $(204.914 \pm 2.20 \mathrm{U} / \mathrm{L})$ level in diabetic control rats is a sign of hepatic injury due to leakage of these enzymes from liver cytosol to the blood stream. From the result, it is evident that the ME maintains the AST and ALT level indicating the hepatoprotective role in thwarting diabetic complications. Oral doses of mistletoe Loranthus micranthus extracts to Wistar rats at $551 \mathrm{mg} / \mathrm{kg} \mathrm{b.w.} \mathrm{and} 827 \mathrm{mg} / \mathrm{kg}$ b.w. had significantly lower ALT activities to 15.96 and $14.24 \mathrm{U} / \mathrm{L}$ and mild variations in the AST activities of 31.99 and $34.30 \mathrm{U} / \mathrm{L}$ [35].

Table 2: Effect of ME on TG and TC in STZ-NIC induced diabetic rats $(n=5)$

\begin{tabular}{lllll}
\hline \multirow{2}{*}{ Groups } & TG $(\mathbf{m g} / \mathbf{d L})$ & & TC $(\mathbf{m g} / \mathbf{d L})$ & \\
\cline { 2 - 5 } & Before treatment & After treatment & Before treatment & After treatment \\
\hline Control & $95.36 \pm 1.94$ & $94.92 \pm 1.75$ & $154.94 \pm 2.25$ & $154.388 \pm 2.23$ \\
Control+J. gossypifolia & $95.76 \pm 1.86$ & $95.92 \pm 1.96$ & $156.952 \pm 2.28$ & $160.168 \pm 2.25$ \\
Diabetic group & $207.21 \pm 3.15^{\#}$ & $248.11 \pm 3.98^{\#}$ & $246.542 \pm 3.24^{\#}$ & $279.420 \pm 3.99^{\#}$ \\
Diabetic+J. gossypifolia ME (LD) & $205.44 \pm 3.26$ & $129.38 \pm 2.97^{*}$ & $248.602 \pm 3.27$ & $195.116 \pm 2.92^{*}$ \\
Diabetic+J. gossypifolia ME (HD) & $203.22 \pm 3.49$ & $117.07 \pm 2.94^{*}$ & $246.32 \pm 3.29$ & $178.801 \pm 2.25^{*}$ \\
Diabetic+metformin & $201.72 \pm 3.18$ & $107.84 \pm 2.18^{*}$ & $243.436 \pm 3.87$ & $166.802 \pm 2.14^{*}$ \\
\hline
\end{tabular}

Values are expressed as means \pm SD $(n=5)$ from three independent experiments. Statistical evaluation was done by one-way ANOVA followed by DMRT. * $<<0.05$ as compared with diabetic group, ${ }^{\#} \mathrm{p}<0.05$ as compared with control group. J. gossypifolia: Jatropha gossypifolia, LD: Low dose, HD: High dose, STZ-NIC

Streptozotocin-nicotinamide, ME: Methanolic extract, TG: Triglyceride, TC: Total cholesterol

Table 3: Effect of ME on lipid profile in STZ-NIC induced diabetic rats (n=5)

\begin{tabular}{|c|c|c|c|c|c|c|}
\hline \multirow[t]{2}{*}{ Groups } & \multicolumn{2}{|c|}{ HDL (mg/dL) } & \multicolumn{2}{|l|}{ LDL (mg/dL) } & \multicolumn{2}{|c|}{ VLDL (mg/dL) } \\
\hline & $\begin{array}{l}\text { Before } \\
\text { treatment }\end{array}$ & $\begin{array}{l}\text { After } \\
\text { treatment }\end{array}$ & $\begin{array}{l}\text { Before } \\
\text { treatment }\end{array}$ & $\begin{array}{l}\text { After } \\
\text { treatment }\end{array}$ & $\begin{array}{l}\text { Before } \\
\text { treatment }\end{array}$ & $\begin{array}{l}\text { After } \\
\text { treatment }\end{array}$ \\
\hline Control & $58.99 \pm 1.92$ & $58.22 \pm 1.81$ & $76.87 \pm 1.57$ & $77.18 \pm 1.42$ & $19.07 \pm 1.08$ & $18.98 \pm 1.05$ \\
\hline Control+J. gossypifolia & $59.14 \pm 1.21$ & $58.84 \pm 1.63$ & $78.67 \pm 1.81$ & $82.12 \pm 1.97$ & $19.15 \pm 1.04$ & $19.19 \pm 1.06$ \\
\hline Diabetic group & $35.04 \pm 1.23^{\#}$ & $21.72 \pm 1.07^{\#}$ & $170.08 \pm 2.85^{\#}$ & $209.07 \pm 3.48^{\#}$ & $41.44 \pm 1.69^{\#}$ & $49.62 \pm 1.89^{\#}$ \\
\hline Diabetic+J.gossypifolia ME (LD) & $35.38 \pm 1.11$ & $49.83 \pm 1.96 *$ & $172.94 \pm 2.54$ & $120.17 \pm 2.24^{*}$ & $41.08 \pm 1.93$ & $25.87 \pm 1.32 *$ \\
\hline Diabetic+J. gossypifolia ME (HD) & $35.88 \pm 1.21$ & $54.38 \pm 1.08^{*}$ & $169.79 \pm 2.86$ & $101.31 \pm 2.04^{*}$ & $40.64 \pm 1.75$ & $23.40 \pm 1.37^{*}$ \\
\hline Diabetic+metformin & $36.28 \pm 1.62$ & $56.68 \pm 1.07 *$ & $166.83 \pm 2.64$ & $88.62 \pm 1.59 *$ & $40.35 \pm 1.95$ & $21.56 \pm 1.12^{*}$ \\
\hline
\end{tabular}

Values are expressed as means \pm SD $(n=5)$ from three independent experiments. Statistical evaluation was done by one-way ANOVA followed by DMRT. *p $<0.05$ as compared with diabetic group, $\# \mathrm{p}<0.05$ as compared with control group. J. gossypifolia: Jatropha gossypifolia, LD: Low dose, HD: High dose, STZ-NIC

Streptozotocin-nicotinamide, ME: Methanolic extract, HDL: High-density lipoprotein, LDL: Low-density lipoprotein, VLDL: Very low-density lipoprotein

Table 4: Effect of ME on AST and ALT in STZ-NIC induced diabetic rats (n=5)

\begin{tabular}{lllll}
\hline \multirow{2}{*}{ Groups } & AST (U/L) & & ALT (U/L) \\
\cline { 2 - 3 } & Before treatment & After treatment & Before treatment & After treatment \\
\hline Control & $33.778 \pm 1.21$ & $33.59 \pm 1.72$ & $34.960 \pm 1.60$ \\
Control+J. gossypifolia. & $34.732 \pm 1.25$ & $34.704 \pm 1.39$ & $34.720 \pm 1.03$ & $35.370 \pm 1.43$ \\
Diabetic group & $145.734 \pm 2.36^{\#}$ & $191.314 \pm 2.82^{\#}$ & & $179.340 \pm 2.50^{\#}$ \\
Diabetic+J. gossypifolia ME (LD) & $145.366 \pm 2.27$ & $38.236 \pm 1.29^{*}$ & & $179.286 \pm 2.48$ \\
Diabetic+J. gossypifolia ME (HD) & $144.79 \pm 2.45$ & $36.488 \pm 1.26^{*}$ & $204.914 \pm 2.20^{\#}$ & $179.550 \pm 2.42$ \\
Diabetic+metformin & $146.132 \pm 2.72$ & $31.28 \pm 1.58^{*}$ & $40.236 \pm 2.27^{*}$ & $180.172 \pm 2.29$ \\
\hline
\end{tabular}

Values are expressed as means \pm SD $(n=5)$ from three independent experiments. Statistical evaluation was done by one-way ANOVA followed by DMRT. * $<0.05$

as compared with diabetic group, "

Streptozotocin-nicotinamide, ME: Methanolic extract, AST: Aspartate transaminase, ALT: Alanine transaminase 


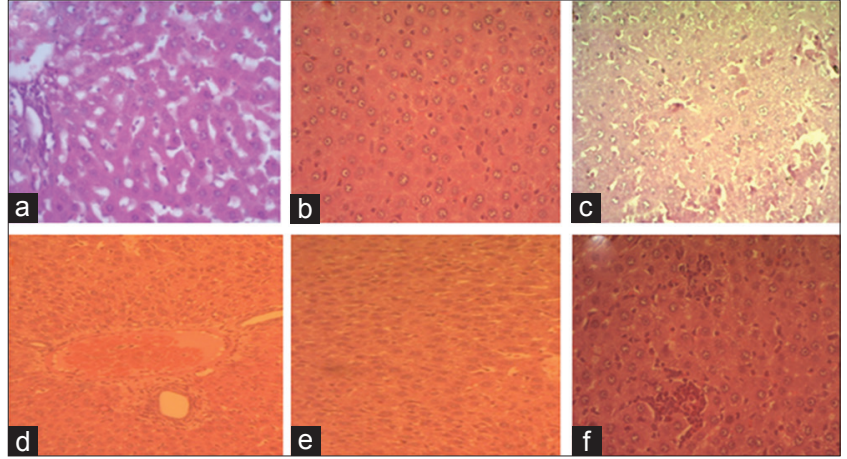

Fig. 1: Histopathology of liver in streptozotocin-nicotinamide induced diabetic rats after 35 days of the treatment with methanolic extract (ME). (a) Control rats (b) control+ME rats showing normal hepatic cells. (c) Diabetic rats showing hepatocellular necrosis. (d and e) ME 50 and $100 \mathrm{mg} / \mathrm{kg}$ b.w. respectively, showing normal hepatocellular with normal cytoplasm and nucleus. (f) Diabetic+metformin (500 mg/kg) showing distinct hepatic layer with normal cytoplasm and nucleus

Table 5: Effect of ME on liver glycogen in STZ-NIC induced diabetic rats $(n=5)$

\begin{tabular}{ll}
\hline Groups & Liver glycogen $\mathbf{~ m g / g}$ \\
\hline Control & $56.14 \pm 1.37$ \\
Control+J. gossypifolia. & $53.42 \pm 1.52$ \\
Diabetic group & $18.74 \pm 0.97^{\#}$ \\
Diabetic+J. gossypifolia ME (LD) & $49.23 \pm 1.20^{*}$ \\
Diabetic+J. gossypifolia ME (HD) & $55.58 \pm 1.47^{*}$ \\
Diabetic+metformin & $59.95 \pm 1.68^{*}$ \\
\hline
\end{tabular}

Values are expressed as means \pm SD ( $n=5)$. Statistical evaluation was done by one-way ANOVA followed by DMRT. ${ }^{*}<<0.05$ as compared with diabetic group, ${ }^{*} \mathrm{p}<0.05$ as compared with control group. J. gossypifolia: Jatropha gossypifolia, LD: Low dose, HD: High dose, STZ-NIC: Streptozotocin-nicotinamide, ME: Methanolic extract

Effect of ME on glycogen content in STZ-NIC induced diabetic rats The liver plays an important role in postprandial hyperglycemia which is involved in the synthesis of glycogen. Glycogen synthase is activated by synthase phosphatase resulting in glycogenesis. Oral administration of ME (50 and $100 \mathrm{mg} / \mathrm{kg}$ b.w.) significantly increased the liver glycogen level of $49.23 \pm 1.20$ and $55.58 \pm 1.47 \mathrm{mg} / \mathrm{g}$, respectively, when compared with the diabetic rats which showed $18.74 \pm 0.97 \mathrm{mg} / \mathrm{g}$ of glycogen. Helianthus annuus L., seed ethanolic extract 250 and $500 \mathrm{mg} / \mathrm{kg}$ b.w. for 21 days in STZ-NIC induced diabetic rats resulted in significant increase in liver glycogen of $12.65 \pm 0.32$ and $13.32 \pm 0.28 \mathrm{mg} / \mathrm{g}$, respectively [36]. The diabetic rats treated with ME fetched back liver glycogen to normal levels, and this may be due to the improved secretion of insulin, resulting in the augmentation of glycogenesis (Table 5).

\section{Histopathological studies}

Fig. 1 summarizes the histology of liver in control and experimental rats. Control rats (Fig. 1a and b) showing normal hepatic cells. Diabetic control rats (Fig. 1c) showing hepatocellular necrosis and fading nuclei in STZ-NIC induced rats. The experimental group rats which received ME 50 and $100 \mathrm{mg} / \mathrm{kg}$ b.w. (Fig. 1d and e) indicated the section of liver showing hepatocellular manner with normal nucleus and cytoplasm. Diabetic rats treated with metformin ( $500 \mathrm{mg} / \mathrm{kg}$ b.w.) showed separate hepatic layer with normal nucleus and cytoplasm. A similar result was observed in Ficus amplissima smith, bark extracts $(50,100$, and $150 \mathrm{mg} / \mathrm{kg}$ b.w.) in STZ induced diabetic rats showing normal hepatocellular architecture in experiment groups and liver was necrotized in diabetic control rats [37]. Histopathological study of the liver revealed that the ME significantly enhanced central vein and lobular architecture.

\section{CONCLUSION}

From the above results, it is concluded that J. gossypifolia ME has exhibited significant hypoglycemic and hypolipidemic potential. In this study, we have demonstrated that ME have a favorable effect on creatinine, TG, TC, HDL, LDL, VLDL, ALP, and AST bringing the levels close to normal level. This indicates that the ME of J. gossypifolia may possibly be used for the development of a pharmaceutical drug for treating diabetes and associated complications.

\section{ACKNOWLEDGMENT}

The authors sincerely thank the Center for Animal House, SRM Medical College, Chennai, India, providing facility to carry out the in vivo studies.

\section{REFERENCES}

1. Petersen KF, Shulman GI. Etiology of insulin resistance. Am J Med 2006;119:S10-6

2. Abidi A, Rizvi DA, Ahmad A. Pharmacoeconomic and drug utilization study of antidiabetic therapy in a tertiary care teaching. Asian J Pharm Clin Res 2016;3:371-5.

3. Davidson MB. American diabetes association diagnosis and classification of diabetes mellitus. Diabetes Care 2010;33:62-9.

4. Anindita B, Bithin M, Sandip M, Kausik C, Tapan S. In vitro antidiabetic and anti-oxidant activities of ethanol extract of Tinospora sinensis. Int J Curr Pharm 2017;9:42-7.

5. Ashok KS, Viney C, Chailendra KS, Kumar KA. Different chemical, biological and molecular approaches for anti-hyperlipidemic therapy with special emphasis on anti-hyperlipidemic agents of natural origin. J Crit Rev 2014;1:1-9.

6. Liu X, Kim JK, Li Y, Li J, Liu F, Chen X. Tannic acid stimulates glucose transport and inhibits adipocyte differentiation in 3T3-L1 cells. J Nutr 2005; 135(2):165-71.

7. Sk G, Ak N, Ghosh R, Mandal P. Elicitation of trigonelline, a hypoglycemic agent in fenugreek sprouts by calcium and nitric oxide priming. J Nutr 2005;135:165-71

8. Mukherjee PK, Maiti K, Mukherjee K, Houghton PJ. Leads from Indian medicinal plants with hypoglycemic potentials. J Ethnopharmacol 2006;106:1-28.

9. Twinkle B, Amit G, Bharat S, Salalkar BK. Assessment of antidiabetic potential of traditional medicinal plants in human whole blood samples. Innov J Health Sci 2017;5:1-4.

10. Kumar JP, Debajyoti D, Nalini P, Prachi J. Traditional indian herb Emblica officinalis and its medicinal importance. Innov J Ayruvedic Sci 2016;4:1-15.

11. Priyanka RS. A systematic review on indian floral biodiversity as eminent reserves for alternative treatment strategy of diabetes mellitus. Int J Pharm Pharm Sci 2016;8:10-9.

12. Sabandar CW, Ahmat N, Jaafar FM, Sahidin I. Medicinal property, phytochemistry and pharmacology of several Jatropha species (Euphorbiaceae): A review. Phytochemistry 2013;85:7-29.

13. Abreu IC, Marinho AS, Paes AM, Freire SM, Olea RS, Borges MO, et al. Hypotensive and vasorelaxant effects of ethanolic extract from Jatropha gossypifolia L. in rats. Fitoterapia 2003;74:650-7.

14. Mishra SB, Vijaykumar M, Ojha SK, Verma A. Antidiabetic effect of Jatropha Curcas L. Leaves extract in normal and alloxan induced diabetic rats. Int J Pharm Sci 2013;5:2081-5.

15. Olayiwola G, Iwalewa E, Omobuwajo O, Adebajo AC, Adeniyi AA, Verspohl EJ. The antidiabetic potential of Jatropha tanjorensis leaves. Niger J Nat Prod Med 2005;8:55-8.

16. Chia-Chi C, Yang MH, Wen HM, Chern JC. Estimation of total flavonoid content in propolis by two complementary colorimetric methods. J Food Drug Anal 2002;10:178-82.

17. McDonald S, Prenzler PD, Antolovich M, Robards K. Phenolic content and antioxidant activity of olive extracts. Food Chem 2001;73:73-84.

18. Silva S, Gomes L, Leitao F, Coelho AV, Vilas-Boa L. Phenolic compounds and antioxidant activity of Olea europaea L. Fruits and leaves. Food Sci Technol Int 2006;12:385-95.

19. van Buren JP, Robinson WB. Formation of complexes between protein and tannic acid. J Agric Food Chem 1969;17:772-7.

20. Torres-Piedra M, Ortiz-Andrade R, Villalobos-Molina R, Singh N, Medina-Franco JL, Webster SP, et al. A comparative study of flavonoid 
analogues on streptozotocin-nicotinamide induced diabetic rats: Quercetin as a potential antidiabetic agent acting via $11 \beta$-hydroxysteroid dehydrogenase Type 1 inhibition. Eur J Med Chem 2010;45:2606-12.

21. Kumar R, Pate DK, Prasad SK, Sairam K, Hemalatha S. Antidiabetic activity of alcoholic leaves extract of Alangium lamarckii thwaites on streptozotocin nicotinamide induced Type 2 diabetic rats. Asian Pac J Trop Med 2011;4:904-9.

22. Kumar V, Ahmed D, Gupta PS, Anwar F, Mujeeb M. Anti-diabetic, anti-oxidant and anti-hyperlipidemic activities of Melastoma malabathricum Linn. Leaves in streptozotocin induced diabetic rats. BMC Complement Altern Med 2013;13:222

23. Yang BK, Kim DH, Jeong SC, Das S, Choi YS, Shin JS, et al. Hypoglycemic effect of a Lentinus edodes exo-polymer produced from a submerged mycelial culture. Biosci Biotechnol Biochem 2002;66(5):937-42.

24. Sangeetha MS, Priyanga S, Hemmalakshmi S, Devaki K. In vivo antidiabetic potential of Cyclea peltata in streptozotocin-induceddiabetic rats. Asian J Pharm Clin Res 2015;8:103-8.

25. Seifter S, Dayton S, Novic B, Muntwyler E. The estimation of glycogen with the anthrone reagent. Arch Biochem 1950;25(1):191-200.

26. Swanston-Flatt SK, Day C, Bailey CJ, Flatt PR. Traditional plant treatments for diabetes. Studies in normal and streptozotocin diabetic mice. Diabetologia 1990;33:462-4.

27. da Silva MS, Sánchez-Fidalgo S, Talero E, Cárdeno A, da Silva MA, Villegas W, et al. Anti-inflammatory intestinal activity of Abarema cochliacarpos (Gomes) Barneby and Grimes in TNBS colitis model. J Ethnopharmacol 2010;128(2):467-75.

28. Muthusamy VS, Anand S, Sangeetha KN, Sujatha S, Arun B,
Lakshmi BS. Tannins present in Cichorium intybus enhance glucose uptake and inhibit adipogenesis in 3T3-L1 adipocytes through PTP1B inhibition. Chem Biol Interact 2008;174(1):69-78.

29. Chaitanya SK, Hemanth KV, Sunitha RM. Activity of polyherbal extract against bacteria causing skin infections in diabetic patients. Asian J Pharm Clin Res 2017;10:147-9.

30. Prasad PS, Kanti HP, Sudipta D. In vitro hypoglycemic and antimicrobial activity of cucumis callosus (Rottl). Cogn. fruit. Asian J Pharm Clin Res 2016;9:77-8.

31. Kumaresan PT, Saravanan S, Subish R. In vitro anti diabetic activity of Morinda tinctoria fruits extracts. Asian J Pharm Clin Res 2014;7:90-2.

32. Chinnala KM, Achanta P, Vangala VL, Elsani MM. Evaluation for nephroprotective activity of ethanolic extract of Allium cepalinn in gentamicin-induced nephrotoxicity in rats. Asian J Pharm Clin Res 2017; $10: 356-9$.

33. Rout SP, Kar DM, Maharana L. Anti-hyperglycemic effect of different fractions of Annona reticulata leaf. Asian J Pharm Clin Res 2016;9:256-62.

34. Vidhya R, Renitta ER. Evaluation of antihyperglycemic and antihyperlipidemic activities of an edible gastropod (Achatina fulica) in alloxan-induced diabetic mice. Asian J Pharm Clin Res 2016;9:206-11.

35. Edem DO, Usoh IF. Biochemical changes in Wistar rats on oral doses of mistletoe (Loranthus micranthus). Am J Pharm Toxicol 2009;4:94-7.

36. Saini S, Sharma S. Streptozotocin-nicotinamide induced Type 2 diabetes mellitus. Int J Pharm Pharm Sci 2013;5:382-7.

37. Arunachalam K, Parimelazhagan T. Antidiabetic activity of Ficus amplissima Smith. bark extract in streptozotocin induced diabetic rats. J Ethnopharmacol 2013;147:302-10. 